\title{
Impact of Different Application Methods and Concentrations of Ascorbic Acid on Sugar Beet under Salinity Stress Conditions
}

\author{
Eman M. Abdel Fatah ${ }^{1}$ and K.A. Sadek ${ }^{2}$ \\ ${ }^{1}$ Physiol. and Chem, Res. Dept., Sugar Crops Res. Inst., Agric. Res. Center, Giza, Egypt \\ ${ }^{2}$ Agron. Res. Dept., Sugar Crops Res. Inst., Agric. Res. Center, Giza, Egypt
}

\begin{abstract}
Salinity is one of the major abiotic stresses which affected on plant growth and reduces plant productivity. Antioxidants compounds considered as one of the methods and strategies to ameliorate the deleterious effects of salinity stress on plants to reduce the effect of oxidative stress. Field experiment was carried out at Sinnuris District which located mainly adjacent to Lake Qarun (saline soil) at El Fayoum Governorate (latitude $29^{\circ} 20$ and $29^{\circ} 30 \mathrm{~N}$ and longitude $30^{\circ} 43$ and $30^{\circ} 56 \mathrm{E}$ ) during 2015/2016 and 2016/2017 growing seasons to study the effect of relation between three application methods (seed soaking, foliar spraying and seed soaking plus foliar spraying together) and four concentrations (without treatment, tap water, 100 ppm and $200 \mathrm{ppm}$ of ascorbic acid) of ascorbic acid on some biochemical and physiological characteristics, antioxidant enzyme activity as well as growth, yield and quality of sugar beet (Beta vulgaris var. saccharifera, L.) under salt stress conditions. The treatments were arranged in a strip-split plot design with three replications. The vertical plots were occupied with three application methods while, the horizontal plots were devoted to four ascorbic acid treatments.

Results showed that application of soaking sugar beet seed in ascorbic acid (AsA) plus foliar spraying at 50 and 70 days from sowing significantly increased chlorophyll $\mathrm{a}, \mathrm{b}$ and carotenoides, LAI, catalase (CAT) and superoxide dismutase (SOD) activities, yield components and sucrose $\%$ in both seasons while juice impurities $(\mathrm{K}, \mathrm{Na}$ and $\alpha$-Amino $-\mathrm{N})$ were decreased and significantly increased root yield by $(9.19,9.63 \%)$ and sugar yield by $(13.43,15.59 \%)$ compared to AsA applied as a seed soaking or foliar spray in the $1^{\text {st }}$ season and the same trend was attained in the $2^{\text {nd }}$ season.

Applying 200 ppm of ascorbic acid was more effective and significantly increased root and sugar yields and sucrose $\%$ and caused more reduction in juice impurities in comparison to the control, in both seasons.

Higher stomata area, lower stomata density and stomata closure $\%$ were recorded by seed soaking plus foliar spraying with 200 ppm AsA treatment for upper and lower surface of sugar beet leaf.

Applying seed soaking plus foliar spraying by 200 ppm of ascorbic acid significantly increased root yield by (6.99 and 4.54 ton/fed) and sugar yield by ( 2.19 and 2.06 ton/fed) over that gained by untreated plants in the $1^{\text {st }}$ and $2^{\text {nd }}$ seasons.
\end{abstract}

Keywords: Sugar beet, salinity, ascorbic acid, application methods, enzyme activities, stomata.

\section{INTRODUCTION}

Salt stress is one of the world wide abiotic factors which caused inhibition of soil microorganisms' and cause damage in plant growth and its yield. In most of the cases, the negative effects of salinity have been attributed to increase in $\mathrm{Na}+$ and $\mathrm{Cl}$ - ions. In different plants, salinity at higher levels may cause membrane damage, nutrient imbalance, altered levels of growth regulators, enzymatic inhibition and metabolic dysfunction, including photosynthesis which ultimately leads to plant death (Hasanuzzaman et al. 2012). Biochemical and molecular studies of salt stress responses in plants have revealed significant increases of reactive oxygen species (ROS), including singlet oxygen $\left(1 \mathrm{O}_{2}\right)$, superoxide $\left(\mathrm{O}_{2-}\right)$, hydroxyl radical $(\mathrm{OH} \bullet)$ and hydrogen peroxide $\left(\mathrm{H}_{2} \mathrm{O}_{2}\right)$ (Ahmad et al. 2012). These radicals cause peroxidation of membrane lipids, destruction of skeleton structure and dysfunction of cell (Yin, et.al 2011). El-Fayoum Governorate is a natural depression in the Eocene limestone plateau located at about $90-\mathrm{km}$ southwest of Cairo. Sinnuris District in the eastern-north part of Fayoum depression. These areas are located mainly adjacent to Lake Qarun which covers an area of about $210 \mathrm{~km} 2$ of salty water of average $33.9-37.6$ g. $\mathrm{L}^{-1}$ (FWMP, 1999) however the increase in salinity indicates annual salt accumulation in Qarun is still as much as 70-85 mln.kg/year (Shadrin et al. 2016) and thus the capacity of the salt extraction process must be increased to prevent further salinity increases in the future, where, poor drainage conditions, shallow saline groundwater, and clayey soils with low permeability occurred, soils are also very saline. The storing capacity of the lake and its salinity are considered main limiting factors for agriculture development in Fayoum Governorate (Euroconsult, 1992). In order to tackle salinity problem, choice of crop that can utilize or tolerate high salt levels in soil and/or irrigation water should be included in agricultural programs. Sugar beet is one of the most salt tolerant crops, but with less tolerance during germination, emergence and seedling stage (Maas, 1986). Rhoades and Loveday (1990) indicated that, sugar yield of sugar beet was not affected by salinity up to an electrical conductivity value of soil paste extract (ECe) of $7 \mathrm{dSm}$.

Over-production of reactive oxygen species (ROS) in plants under stress conditions is a common phenomenon. Plants tend to counter this problem through their ability to synthesize ROS neutralizing substances including non-enzymatic and enzymatic antioxidants. In this context, ascorbic acid (Vitamins C) is one of the universal non-enzymatic antioxidants having substantial potential of not only scavenging ROS, but also modulating a number of fundamental functions in plants both under stress and non-stress conditions. Most efficient role of AsA is to protect lipids and proteins against salinity -induced oxidative 
adversaries (Naz et al., 2016), enhancing plant growth, rate of photosynthesis, transpiration, and oxidative defense potential and photosynthetic pigments, it also has a role in cell division and cell enlargement, stomatal regulations (Barth et al., (2006) , as well as acting as a co-factor for many enzymes. Additionally, ascorbic acid protects metabolic processes against $\mathrm{H}_{2} \mathrm{O}_{2}$ and toxic derivatives of oxygen which affect various enzyme activities and decreases the damage caused through oxidative processes by functioning in synergy with other stabilizing membranes and antioxidants (Shao et al., 2008). Foliar application of AA at $200 \mathrm{mg} \mathrm{1-1}$ decreased the adverse effect of salinity that was accompanied by a significant increase in plant growth of flax cultivars (El-Hariri et al. 2010). Applied ASA $(250 \mathrm{mg} / \mathrm{L})$ as (seed soaking, foliar spraying or seed soaking and foliar spraying together) were the most effective in increasing all yield and it's parameters compared with water as control and decreased the harmful effects of salinity stress of faba bean plants (Sakr et al. 2014). Abido et al. (2015) showed that foliar spraying with $150 \mathrm{ppm}$ of ascorbic acid improved growth attributes, yield and its components of sugar beet. Samin et al. (2016) observed that treated Solanum melongena with ascorbic acid (100ppm and 200ppm) showed increase in plant height, root length, in saline environments as compared to control plants . Elsayed (2017) reported that, the interaction between salinity stress and seed soaking ( $0.5 \mathrm{mM}$ ASA) was significant for whole plant and root fresh and dry weights, and chlorophyll content index of sugar beet. Jagdish et al. (2017) recorded that, foliar spraying $1.0 \mathrm{mM}$ ascorbic acid, improved the SOD activity, total chlorophyll, yield attributes, of mungbean (Vigna radiata L.) under salt stress condition.

The current study took-place to study the effects of different Ascorbic acid (ASA) concentrations and methods of their application on yield and quality of sugar beet under Sinnuris District conditions, Fayoum governorate, Egypt.

\section{MATERIALS AND METHODS}

Field experiments was conducted at Sinnuris District, Fayoum Governorate (latitude $29^{\circ} 20$ and $29^{\circ} 30 \mathrm{~N}$ and longitude $30^{\circ} 43$ and $30^{\circ} 56 \mathrm{E}$ ) during $2015 / 2016$ and 2016/2017 seasons to evaluated different ascorbic acid (AsA) application methods and concentrations and their interactions on some Biochemical and physiological Characteristics, antioxidant enzyme activity as well as growth, yield and quality of sugar beet (Beta vulgaris var. saccharifera, L.) grown under salinity stress condition. This area is mainly located adjacent to Lake Qarun where poor drainage conditions, shallow saline groundwater, and clayey soils with low permeability occurred. In the study area, soil is also very saline (Fig. 1). The present work included 12 treatments, represented the combinations of three application methods (seed soaking, foliar spraying and seed soaking plus foliar spraying) and four ascorbic acid treatments (without treatments (control), tap water, 100 and $200 \mathrm{ppm}$ ). The treatments were arranged in a strip plot design in three replicates. The vertical plots were occupied with three application methods while, the horizontal plots were devoted to the four ascorbic acid treatments. Each experiment basic unit area was $15.00 \mathrm{~m}^{2}$ including five ridges of $0.60 \mathrm{~m}$ apart and $5.0 \mathrm{~m}$ long, with $20-\mathrm{cm}$ hill spacing.

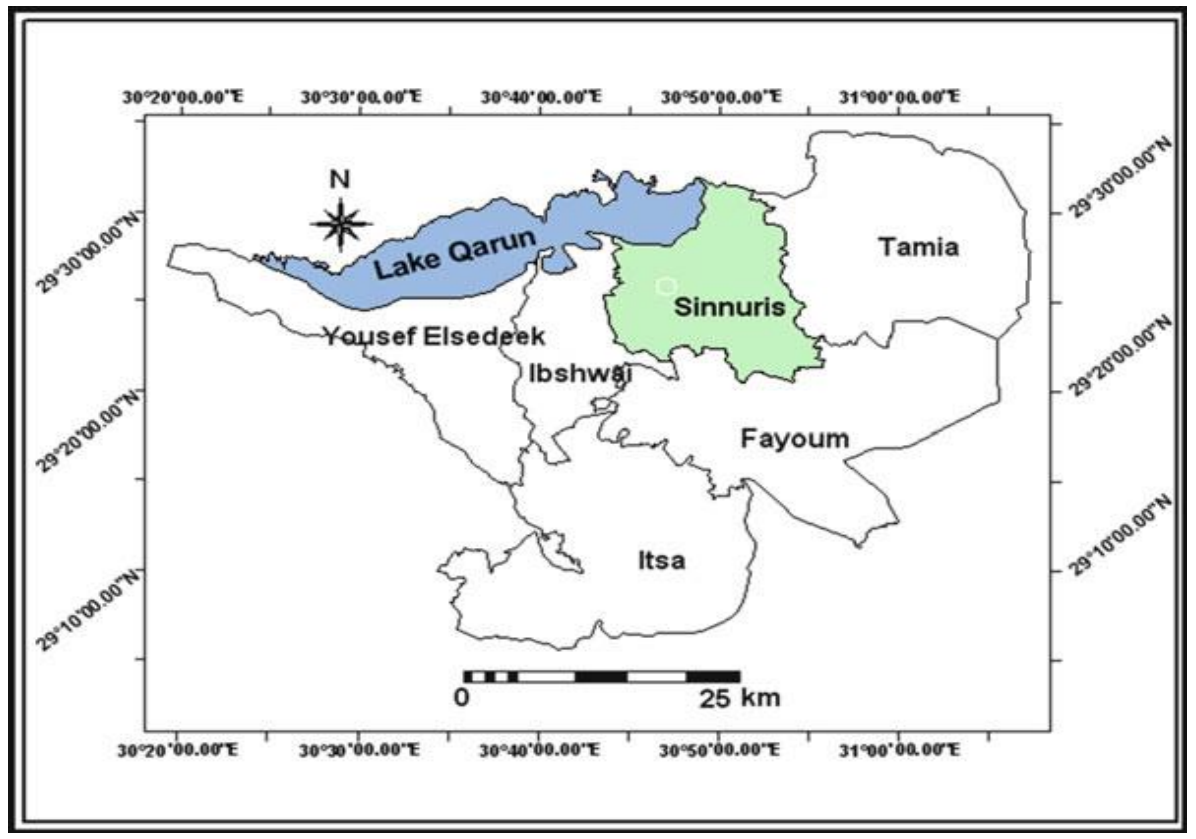

Fig. 1: Location map of the study area

Seeds soaking treatments were done for 12 hours in water or ASA, and then air dried before sowing, whereas foliar spraying treatment or seeds soaking and foliar spraying together treatment were sprayed with foliar solution volume (350 L/faddan) by hand sprayer (for experimental plots) after 50 and 
70 days from sowing (DFS) until saturation point. Ascorbic acid was obtained from El- Gomhouria CO, for Trading Chemicals and Medications. Seeds of sugar beet multi-germ variety "Magribel" were sown at $20^{\text {th }}$ and $26^{\text {th }}$ October, while harvesting was done 7 months later in the first and second seasons. Soil samples were taken at random from the experimental

Table.1 Physical properties and some chemical analysis of experimental soils for 2015/2016 and 2016/2017 seasons

\begin{tabular}{|c|c|c|c|c|c|c|c|c|}
\hline \multicolumn{6}{|c|}{ Physical properties } & \multicolumn{3}{|c|}{ Chemical properties } \\
\hline Seasons & Fine sand \% & Silt \% & Clay \% & \multicolumn{2}{|c|}{ Texture } & pH (1:2:5) & EC & $/ \mathbf{m})$ \\
\hline $2015 / 2016$ & 24.70 & 37.10 & 38.20 & \multirow{2}{*}{\multicolumn{2}{|c|}{ Clay loam }} & 8.16 & & \\
\hline $2016 / 2017$ & 25.30 & 36.90 & 37.80 & & & 8.14 & & \\
\hline \multicolumn{5}{|c|}{ Soluble Cations (meq/l) } & \multicolumn{4}{|c|}{ Soluble Anions $(\mathrm{meq} / \mathrm{l})$} \\
\hline & $\mathbf{C a}^{++}$ & $\mathbf{M g}^{++}$ & $\mathrm{Na}^{+}$ & $\mathbf{K}^{+}$ & $\mathrm{CO}_{3}^{-}$ & $\mathrm{Cl}^{-}$ & $\mathrm{SO}_{4}^{-}$ & $\mathrm{CO}_{3}=$ \\
\hline $2015 / 2016$ & 25.21 & 19.19 & 40.20 & 1.25 & .69 & 70.90 & 8.26 & - \\
\hline $2016 / 2017$ & 25.70 & 19.55 & 39.60 & 1.22 & .72 & 70.71 & 8.64 & - \\
\hline \multicolumn{4}{|c|}{ Available Macronutrients (mg/kg) } & \multicolumn{5}{|c|}{ Available Micronutrients (mg/kg) } \\
\hline & $\mathbf{N}$ & $\mathbf{P}$ & $\mathbf{K}$ & $\mathbf{F e}$ & Mn & Zn & & \\
\hline $2015 / 2016$ & 39.60 & 5.25 & 147.50 & 12.25 & 6.50 & 1.20 & & \\
\hline $2016 / 2017$ & 42.50 & 4.75 & 145.00 & 11.50 & 7.20 & 0.85 & & \\
\hline
\end{tabular}

\section{Studied traits}

After 120 days from sowing, random samples of sugar beet plants were taken from each sub plot to determine the following traits:

1. Leaf area index $(\mathbf{L A I})=$ leaf area per plant $\left(\mathrm{cm}^{2}\right)$ / Plant ground area $\left(\mathrm{cm}^{2}\right)$.

2. Photosynthetic pigments, i.e. chlorophyll a, b and carotenoides (mg/g leaf fresh weight), which were determined according to the method of Wettstein (1957).

3. Antioxidant Enzyme Activities: Super oxide dismutase (SOD) and Catalase (CAT) activities (Unit $\mathrm{g}^{-1}$ protein) were estimated by the method of Beyer and Fridovich (1987).

4- Leaf stomata measurements: The morphological changes of stomata (stomata density $\left(\right.$ No. $\mathrm{mm}^{2}$ ), area $(\mu \mathrm{m})$ and stomatal closure $(\%)$ for adaxial (upper) and abaxial (lower) surface of fully expanded leaves from mature leaf from different treatments were measured through Transmission Electronic Microscope (TEM) Model JEOL JEM-1400 (Jeol Ltd., Tokyo, Japan) linked with the software program at TEM lab (FA-CURP) Faculty of Agriculture, Cairo University Research Park.

At harvest time (210 day from sowing), ten plants were randomly chosen from each plot to determine the following traits:

1- Root length $(\mathrm{cm})$.

2- Root diameter $(\mathrm{cm})$.

3- Root fresh weight g/plant

4- Weight per plot was obtained and used to calculate root yield per-faddan. site at a depth of $0-30 \mathrm{~cm}$ from soil surface. Mechanical and chemical analyses were carried out according to the standard methods (Ryan et al., 1996) (Table 1). The recommended agricultural practices for growing sugar beet were followed according recommendation.

- Sugar yield (ton $\mathrm{fad}^{-1}$ ) = Root yield (ton) $\mathrm{x}$ Extracted sugar $\%$.

\section{Quality measurements}

1. Sucrose percentage was determined by using Sacharometer on an extract of fresh macerated root according to the procedure of the El-Fayoum Sugar Company (Le-Docte,1972), juice impurities contents $(\mathrm{K}, \mathrm{Na}$ and $\alpha$-amino $\mathrm{N})$ were estimated as meq/100 $\mathrm{g}$ beet were determined by using Analyzer $-\mathrm{HG}$ in reception laboratory in El-Fayoum Company.

2. Sugar lost to molasses percentage (SLM \%) was calculated by the following formula, according to Devillers (1988):

SLM $\%=0.29+(\mathrm{Na}+\mathrm{K}) 0.343+0.094(\alpha-$ amino $\mathrm{N})$.

\section{Statistical analysis:}

The collected data of the studied traits were statistically analyzed as shown by Snedecor and Cochran (1980). Treatments means were compared using LSD test at $5 \%$ of probability.

\section{RESULTS AND DISCUSSIONS}

\section{Photosynthetic pigments, leaf area index and antioxidant enzymes activities:}

Results illustrated in Table (2) showed that, different application methods (seed soaking, foliar spraying and seed soaking plus foliar spraying) significantly affected leaf area index (LAI), photosynthetic pigments, antioxidant enzyme activities, in both seasons. Under saline soil conditions, it was noticed that, treatment of soaking sugar beet seeds before sowing in ascorbic acid 


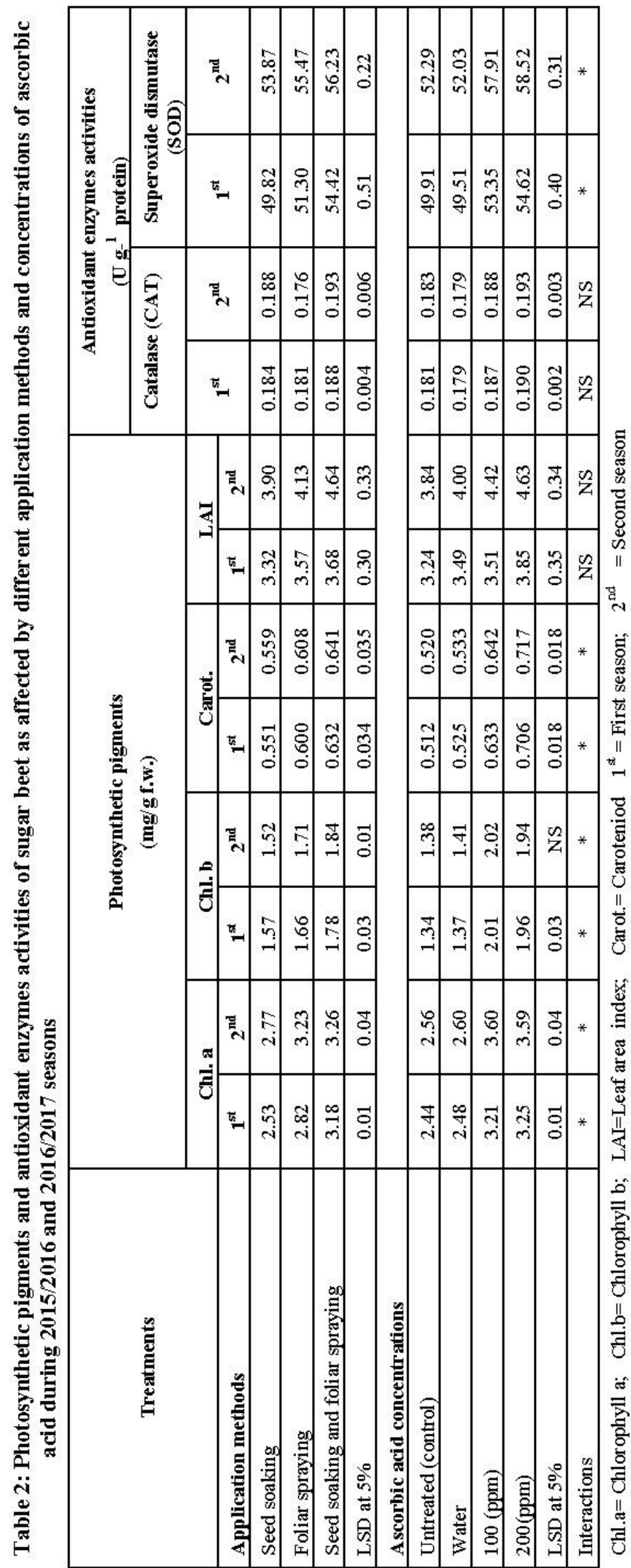


(AsA) solution plus foliar spraying at 50 and 70 days from sowing (DFS) enhanced and produced the maximum LAI (3.68 and 4. 64), chlorophyll a (3.18 and 3.26), chlorophyll $b$ (1.78 and 1.84) and carotenoides (0.632 and 0.641) as well as catalase activity $(0.188$ and 0.193$)$ and superoxide dismutase activity (54.42 and 56.23) compared to the other two application methods in the $1^{\text {st }}$ and $2^{\text {nd }}$ seasons, respectively. This observation coincides with those found by Samin et al. (2016), Elsayed (2017) and Jagdish et al. (2017).

Concerning ascorbic acid concentrations, it was noticed that plants treated with 100 and /or 200 ppm concentrations of ascorbic acid (AsA) significantly affected chlorophyll a, b and carotenoides, LAI, catalase activity (CAT), superoxide dismutase activity (SOD) in both seasons with exception, chlorophyll $b$ which was insignificant in the $2^{\text {nd }}$ season as compared with untreated plant (control) and water tap treatment (Table 2). The maximum increases were observed with 200 ppm ascorbic acid, which enhanced chl.a by (33.20 and 40.23\%), Carotenoids by (37.89 and $37.88 \%)$, LAI by (18.83 and $20.57 \%$ ), catalase activity (CAT) by (4.97 and $5.46 \%$ ), Superoxide dismutase activity (SOD) by (9.44 and $11.91 \%$ ), more than the control(untreated) in the $1^{\text {st }}$ and $2^{\text {nd }}$ seasons, respectively. No significant differences were observed between 100 and 200 ppm of AsA concentrations for chl.a in the $2^{\text {nd }}$ season. Several studies were reported about the AsAregulation of antioxidant defense metabolism in different plants grown under salinity stress conditions, e.g., canola by (Bybordi, 2012), Abelmochus esculentus (Raza et al. 2013), barley (Hordeum vulgare) (Agami, 2014). Furthermore, Athar et al. (2009) found that application of AsA at100 $\mathrm{mg} \mathrm{L}^{-1}$ improved growth, and activities of superoxide dismutase (SOD), and catalase (CAT) antioxidative enzymes in wheat. The stimulation effect of ascorbic acid on plant under stress condition might be due to the substantial role of ascorbic acid in many metabolic and physiological processes and counteracting the adverse effects of salinity (Shaddad et al., 1990), regulation of photosynthesis, hormone biosynthesis and regeneration of other antioxidants, plant defense against oxidization by scavenger of the toxic species of activated oxygen, cofactor of key enzyme as well as the role of ascorbate in photosynthesis and involvement both in the electron transport of photosystems and oxidized system of chloroplasts. Panda and Khan (2003) added that, AsA is absorbed readily after exogenous application and moves within the plant Hameed et al. (2012).

\section{Root length, diameter and fresh weight and root and sugar yields:}

As shown in Table (3) root length, diameter and fresh weight, root and sugar yields/fad significantly affected by the three application methods of AsA acid in both seasons with exception root diameter in the $1^{\text {st }}$ season. Soaking sugar beet seeds before sowing in ascorbic acid (AsA) solution plus foliar spraying at 50 and 70 days from sowing, significantly increased root yield by $(9.19,9.63 \%$ and $9.88,11.02 \%)$ and sugar yield by $(13.43,15.59 \%$ and $5.41,9.24 \%)$ as compared with soaking seed and /or foliar spray in the $1^{\text {st }}$ and $2^{\text {nd }}$ seasons, respectively with insignificant differences between them in both seasons. While foliar spraying came in the second rank. On the other hand, seed soaking application recoded the minimum values of all last mention traits, except for, root and sugar yields which recorded the lowest values with exogenous application in both seasons. Similar trends could be seen in the results of Abido et al. (2015) and Elsayed (2017). By contrast, Azooz et al. (2013) found that pretreatment with ASA resulted in a significant increment of yield of broad bean (vicia faba, L.).

Data in Table (3) indicated that, root length, diameter and fresh weight, root and sugar yields /fad significantly increased due to plants treatment with100 and /or 200 ppm of AsA compared to untreated plant (control) and water tap treatment either soaking or foliar spray in both seasons. The most beneficial AsA concentration was 200 ppm, at which the root were longest $(23.47$ and 24.33 $\mathrm{cm})$ and the widest $(11.00$ and $11.08 \mathrm{~cm})$, produced the greatest fresh weigh per plant $(0.875$ and $0.941 \mathrm{~g} / \mathrm{plant}$ ) and enhanced root yield by (32.89 and $23.27 \%)$ and sugar yield by (20.87and $53.85 \%)$ more than the control in the $1^{\text {st }}$ and $2^{\text {nd }}$ seasons, respectively. Similar results were obtained by Jagdish et al. (2017), Elsayed (2017) and Samin et al. (2016). This is might be attributed to the role of AsA in plant cell division, cell expansion, growth and development and senescence (Zhang 2013). Ascorbic acid beneficial effect on plant growth and root length could be attributed to the involvement of ascorbic acid in root elongation regulation and cell vacuolation (Smirnoff, 1996).

\section{Sucrose \%, potassium, sodium, alphaamino contents and sugar lost to molasses \%:}

Soaking sugar beet seed plus foliar spraying, significantly increased sucrose $\%$ by $1.37,2.08 \%$ and $1.49,2.35 \%$ over the other applications methods, i.e.; soaking seed and /or foliar spray in the $1^{\text {st }}$ and $2^{\text {nd }}$ season, respectively, and gave the best result for the reduction of juice impurities $(\mathrm{K}$, $\mathrm{Na}$ and $\alpha$-Amino $-\mathrm{N}$ ) and sugar lost to molasses $\%$ in both seasons (Table 4). 


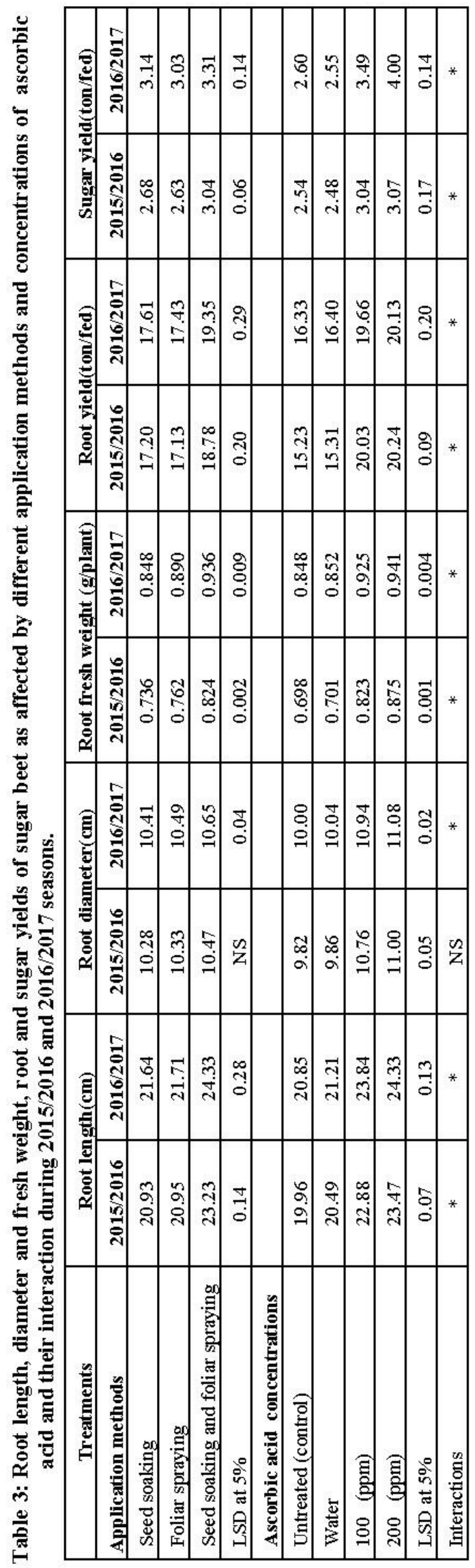


Data in Table (4) also showed that, treated sugar beet plant by 100 and /or 200 ppm ascorbic acid significantly affected sucrose $\%$, impurities (meq/100 $\mathrm{g}$ beet) i.e. $\mathrm{K}$ and $\mathrm{Na}$ in both seasons and sugar lost to molasses\% with exception $\alpha$-Amino- $\mathrm{N}$ in both seasons and sugar lost to molasses $\%$ in the $1^{\text {st }}$ season. The maximum increases were observed by treated plant with 200 ppm ascorbic acid, which enhanced sucrose $\%$ by 1.34 and $1.83 \%$ more than the control and caused significant reduction in juice impurities potassium and sodium in both seasons and sugar lost to molasses \% as compared to control. The same trend was recorded by Abido et al. (2015) whose showed that, spraying sugar beet with $150 \mathrm{ppm}$ ascorbic acid recorded significant increase in sucrose $\%$ than control (without treatment).

Table 4: Sucrose\%, Impurities (Na, K and $\alpha$-amino-N) and sugar lost to molasses (SLM \%) of sugar beet juices as affected by different application methods and concentrations of ascorbic acid and their interaction during 2015/2016 and 2016/2017 seasons.

\begin{tabular}{|c|c|c|c|c|c|c|c|c|c|c|}
\hline \multirow{3}{*}{$\begin{array}{r}\text { Treatments } \\
\text { Application methods } \\
\end{array}$} & \multirow{2}{*}{\multicolumn{2}{|c|}{ Sucrose \% }} & \multicolumn{8}{|c|}{ Impurities (meq/100 g beet) } \\
\hline & & & \multicolumn{2}{|c|}{$\mathbf{K}$} & \multicolumn{2}{|c|}{$\mathrm{Na}$} & \multicolumn{2}{|c|}{$\alpha$-Amino-N } & \multicolumn{2}{|c|}{ SLM\% } \\
\hline & $\mathbf{1}^{\text {st }}$ & $2^{\text {nd }}$ & $1^{\mathrm{st}}$ & $2^{\text {nd }}$ & $\mathbf{1}^{\text {st }}$ & $2^{\text {nd }}$ & $1^{\text {st }}$ & $2^{\text {nd }}$ & $1^{\text {st }}$ & $2^{\text {nd }}$ \\
\hline Seed soaking & 17.53 & 17.87 & 4.01 & 3.96 & 2.23 & 2.33 & 1.34 & 1.35 & 2.56 & 2.57 \\
\hline Foliar spraying & 16.82 & 17.01 & 4.32 & 4.33 & 2.34 & 2.18 & 1.31 & 1.33 & 2.70 & 2.65 \\
\hline Seed soaking and foliar spraying & 18.90 & 19.36 & 3.55 & 3.62 & 2.09 & 2.07 & 1.19 & 1.21 & 2.34 & 2.36 \\
\hline LSD at $5 \%$ & 0.21 & 0.14 & 0.26 & 0.42 & 0.19 & 0.21 & 0.09 & 0.08 & 0.20 & 0.19 \\
\hline \multicolumn{11}{|l|}{ Ascorbic acid concentrations } \\
\hline Untreated (control) & 17.15 & 17.20 & 4.10 & 4.08 & 2.32 & 2.29 & 1.38 & 1.40 & 2.62 & 2.61 \\
\hline Water & 17.19 & 17.41 & 3.98 & 4.04 & 2.26 & 2.25 & 1.35 & 1.38 & 2.56 & 2.58 \\
\hline $100(\mathrm{ppm})$ & 18.17 & 18.68 & 3.95 & 3.91 & 2.12 & 2.13 & 1.22 & 1.20 & 2.49 & 2.47 \\
\hline $200(\mathrm{ppm})$ & 18.49 & 19.03 & 3.83 & 3.83 & 2.19 & 2.10 & 1.18 & 1.21 & 2.46 & 2.44 \\
\hline LSD at $5 \%$ & 0.17 & 0.26 & 0.16 & 0.12 & 0.09 & 0.07 & NS & NS & NS & 0.05 \\
\hline Interactions & $*$ & $*$ & NS & $\mathrm{NS}$ & NS & $\mathrm{NS}$ & NS & NS & NS & NS \\
\hline
\end{tabular}

$\mathrm{K}=$ Potassium; Na= Sodium ; SLM= Sugar lost to molasses; $1^{\text {st }}=$ First season; $2^{\text {nd }}=$ Second season

Analysis of stoma morphological parameters:

The effect of different application methods and concentrations of ascorbic acid (AsA) on morphological changes of stomatal characteristics (Stomata area, density and closure \%) for upper (adaxial) and lower (abaxial) surfaces of sugar beet leaf are shown in Fig. (1 and 2). Individual response to different application method of AsA concentrations was observed for each parameter of stomata. Largest area or size and lower density of stomata for both adaxial and abaxial leaf surfaces, as well as, lower closure\% were recorded by application of seed soaking with AsA and foliar spraying together followed by foliar spraying treatment while the higher density and smaller size of stomata was observed by seed soaking treatment at all AsA concentrations. Treated sugar beet plants with (100 and $200 \mathrm{ppm})$ of AsA or distilled water as seed soaking, foliar spraying or seed soaking plus foliar spraying gave the highest stomata size and lower density and closure\% than those untreated plant (control) for upper and lower surfaces of sugar beet. Increasing concent-rations of ascorbic acid from 100 to $200 \mathrm{ppm}$ lead to an increase in stomata area for both leaf surfaces. The microscopic analysis (Image a, b, c, and d) showed that: higher stomata area, lower stomata density and stomata closure $\%$ were recorded by seed soaking plus foliar spraying application with $200 \mathrm{ppm}$ AsA for upper and lower surfaces of sugar beet leaf (Images a and b). On the other hand, untreated sugar beet plants by AsA (control) affected all stomata parameter and recorded the higher stomata closure \%, and reduced dimensions of stomata in both beet leaf surfaces (Images $\mathrm{c}$ and d) this might be due to Salinity that caused both water stress and osmotic stress in plants and that accumulated salt ions had a toxic effect on plants and decreased leaf turgor, further causing stomata closure and decreases of stomata size (Chaves et al. 2009). Our results also confirm that, stomatal density is inversely related to leaf area and that salinity might increase stomatal density by causing reduction of leaf area. Higher density and smaller size of stomata is a form of adaptation to salinity, because it allowed plants to be more efficient in water transport regulation and transpiration (Dickison, 2000) added that, stomatal density might increase with leaf size reduction to overcome a simple geometric practicality of fitting enough functional stomatal units per unit of leaf surface area to meet the desired $\mathrm{CO}_{2}$ flux and to service photosynthetic capacity (Franks and Farquhar, 2007). Ascorbic acid (AsA) is the major antioxidant that scavenges $\mathrm{H}_{2} \mathrm{O}_{2}$ which an important stress signaling function and promotes stomata closure (Chen and. Gallie 2004). These results are in harmony with those achieved by Arafa et al. (2014) whose concluded that, soaking seeds of sweet pepper plant in ascorbic acid at $50 \mathrm{mg} / \mathrm{L}$ might be useful for overcoming the harmful effects of salinity on the stomata density on both leaf surfaces. 


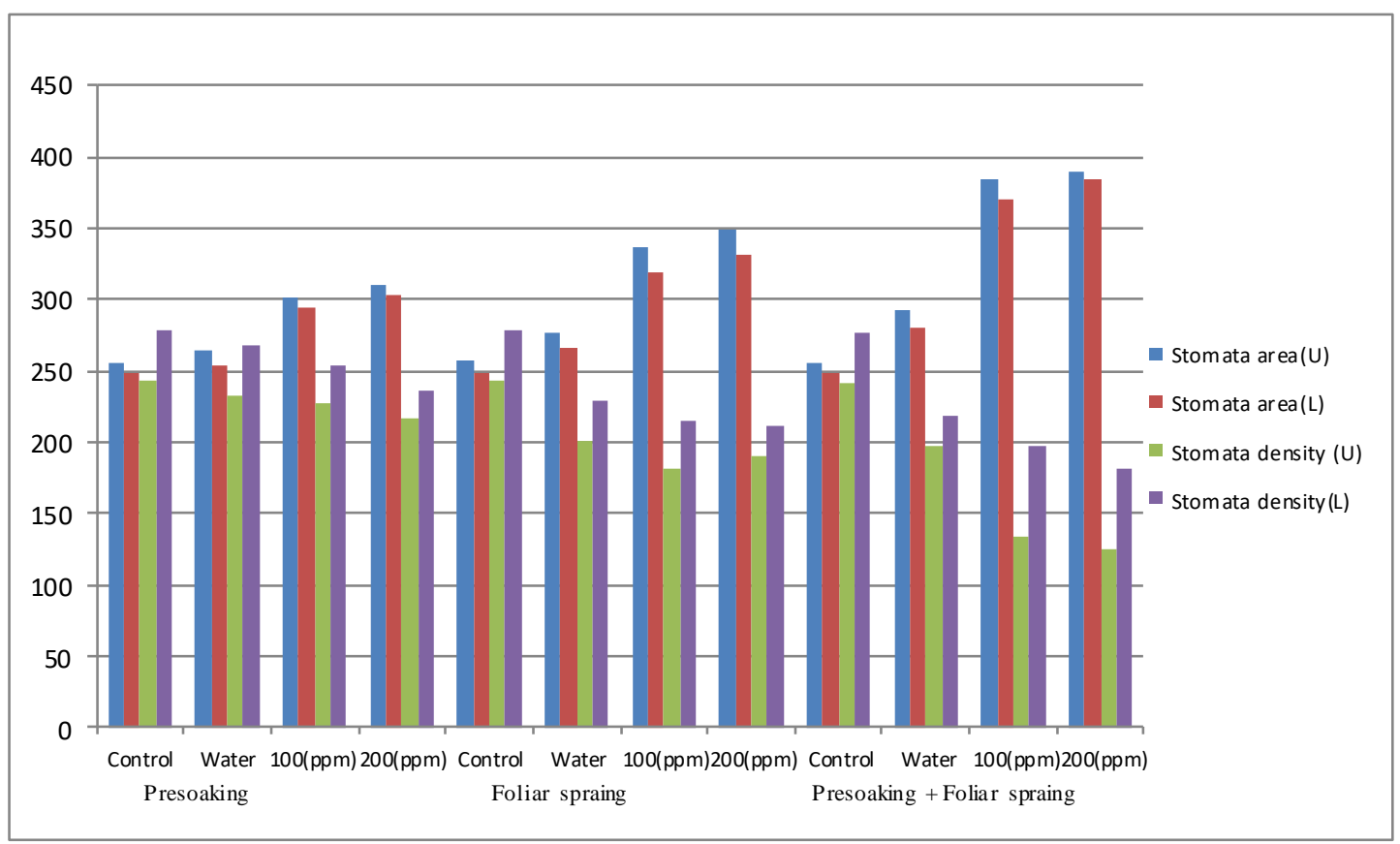

Fig. (1): Stomatal area $(\mu \mathrm{m})$ and density $\left(\mathrm{No} . \mathrm{mm}^{-2}\right)$ for upper $(\mathrm{U})$ and lower $(\mathrm{L})$ surfaces of sugar beet leaf as affected by different application methods of AsA concentrations in 2015/2016 season.

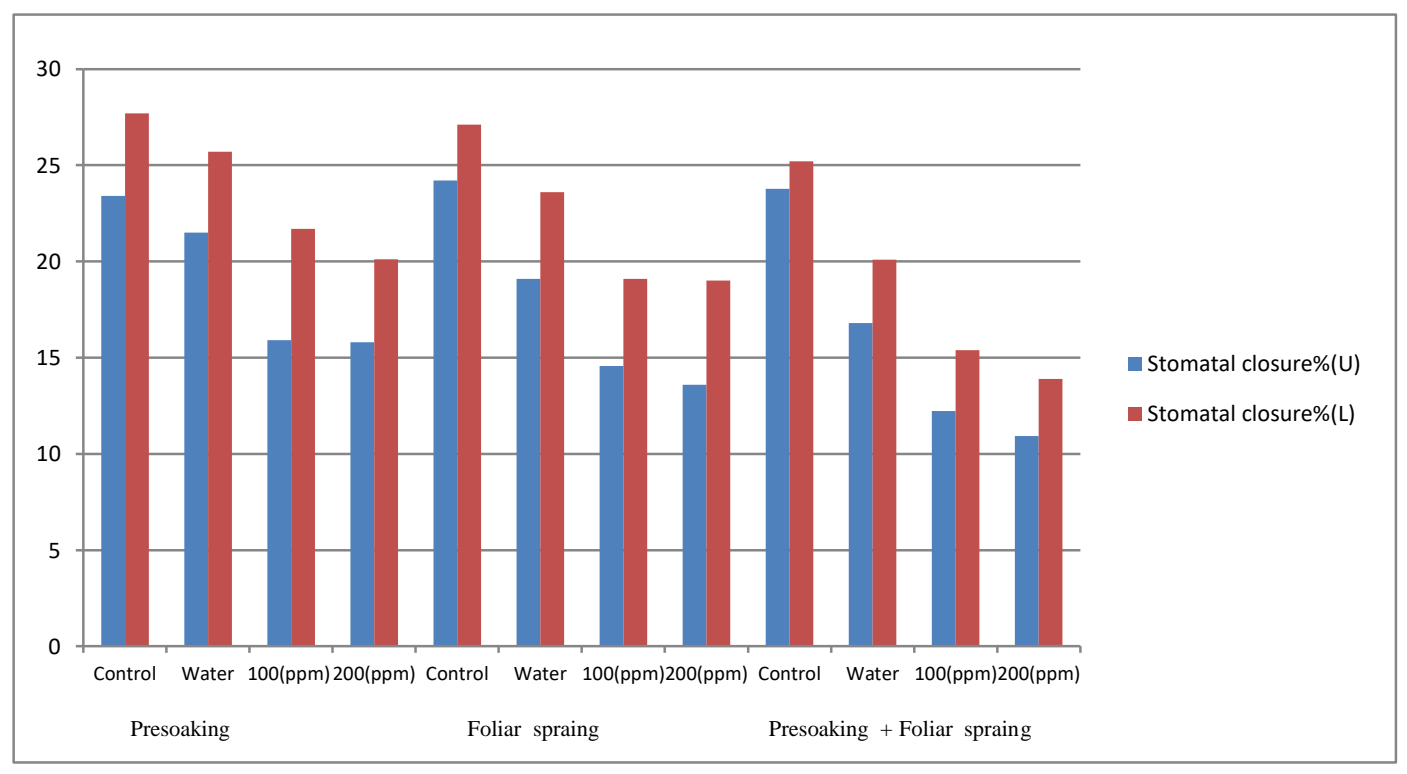

Fig. (2): Stomatal closure\% for upper and lower surfaces of sugar beet leaf as affected by different application methods of AsA concentrations in 2015/2016 

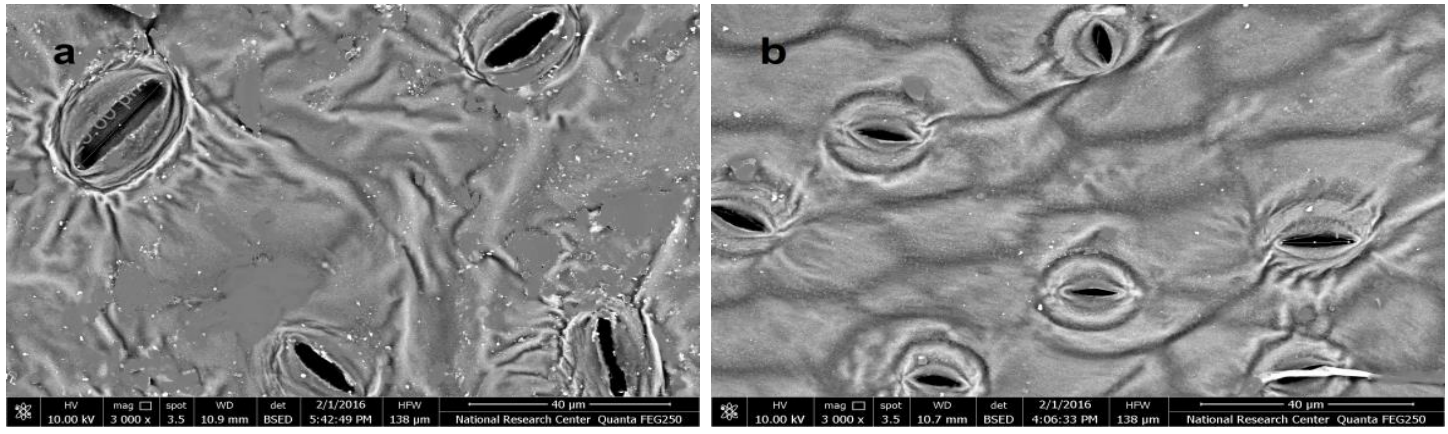

Image a and b: Electron microscopic images (magnification300 $x$ ) of adaxial (imag a) and abaxial (image b) surface of sugar beet leaf showing the effect of seed soaking plus foliar spraying treatment with 200 ppm AsA
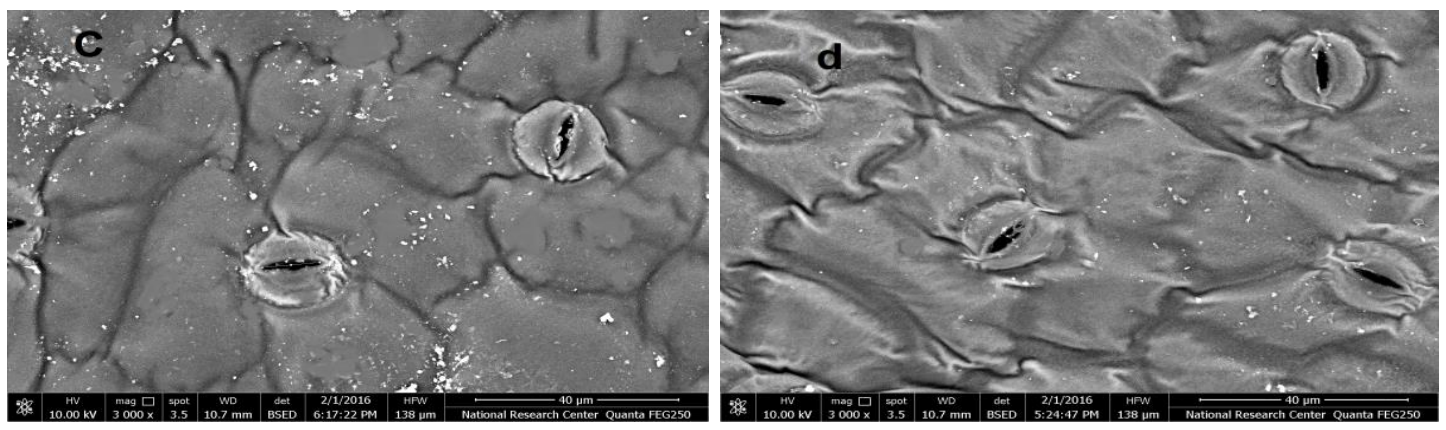

Image $c$ and d: Electron microscopic images (magnification300 $x$ ) of adaxial (image c) and abaxial (image d) surface of sugar beet leaf showing the effect of untreated sugar beet plants with AsA (control)

\section{Interaction effects:}

The effect of the interaction between application methods and different treatments of AsA were significance in their effect on chlorophyll $\mathrm{a}, \mathrm{b}$ and carotenoides, superoxide dismutase (SOD) activity, root and sugar yields and its components and sucrose $\%$ in both seasons as shown in Tables ( 5 and 6) which cleared that, ascorbic acid at $200 \mathrm{ppm}$ when applied as a seed soaking plus foliar spraying proved most effective to reduced salt stress inhibition followed by ascorbic acid at $100 \mathrm{ppm}$. The aforementioned treatment significantly increased root yield by $(6.99,6.80$ and $4.54,3.95$ ton/fad) and sugar yield by $(2.19,1.02$ and $2.06,1.11$ ton/fed) over that gained by untreated plants in the $1^{\text {st }}$ and $2^{\text {nd }}$ seasons, respectively.

\section{CONCLUSION}

It could be concluded that application of ascorbic acid at 200 and or $100 \mathrm{ppm}$ as a seed soaking plus foliar spraying had proved as the most effective treatment to reduced salt stress inhibition and resulted in sugar beet maximum root and sugar yields/fad under this experimental conditions.

\section{REFERENCES}

Abido,W. A. E., M. A. E. Ibrahim and Maha M. El-Zeny (2015). Growth, productivity and quality of sugar beet as affected by antioxidants foliar application and potassium fertilizer top dressing. Asian j. Crops Sci. 7(2):113-127.

Agami, R.A. (2014) Applications of ascorbic acid or proline increase resistance to salt stress in barley seedlings. Bio. Plan. 58 (2): 341-347.

Ahmad, P. ,M. Ozturk and S. Gucel (2012). Oxidative damage and antioxidants induced by heavy metal stress in tow cultivars of mustard (Brassica juncea, L.)plants. Fresenius Environ. Bull. 21:2953-2961

Arafa, A. A., M. A. Khafagy, A. M. Abo- El Kheer, R. A. Fouda and M.F. El-Banna, (2014).stomatal density in the leaves of sweet pepper plant as affected by certain bio-stimulants under salt stress conditions. J. Plant Production, Mansoura Univ., Vol.5 (4): 649 - 662.

Athar, H., A. Khan and M. Ashraf (2009). Including salt tolerance in wheat by exogenously applied ascorbic acid through different modes. J. Plant Nutr. 32(11): 1799-1817. 


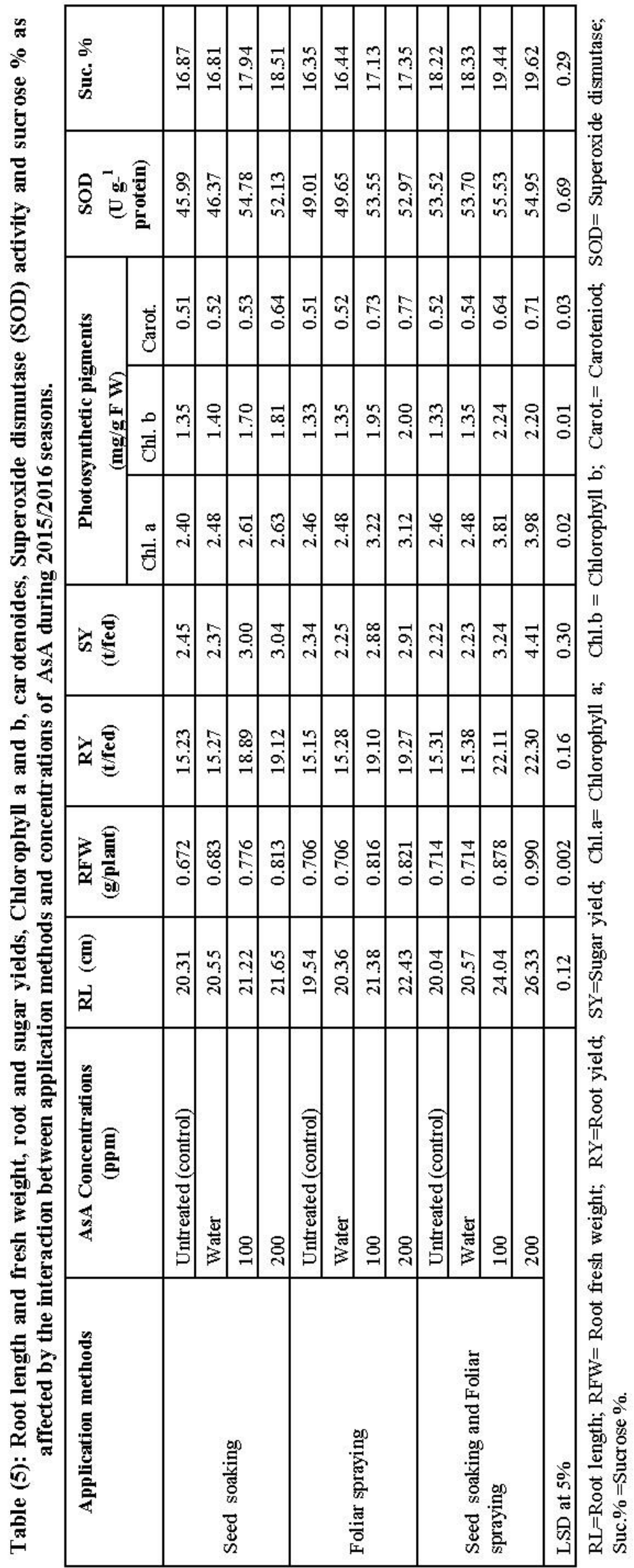


(2)
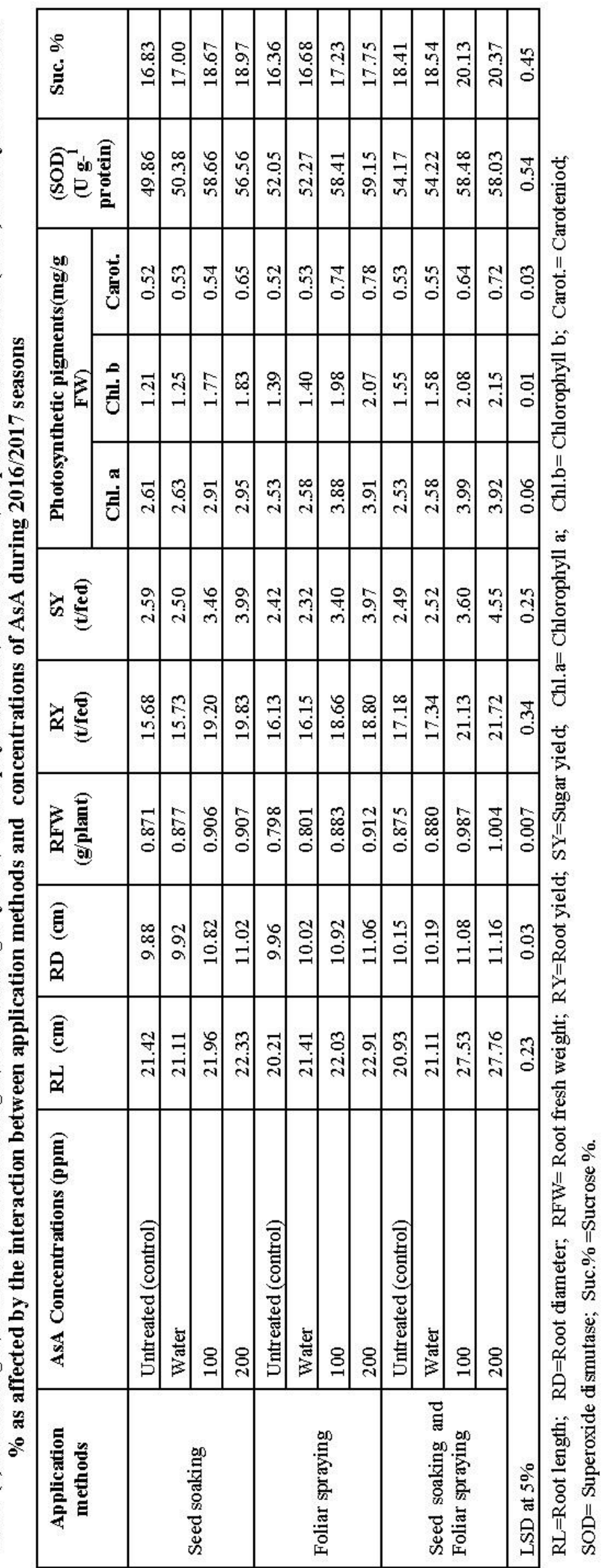
Azooz, M.M., A.M. Alzahrani and M.M. Youssef (2013). The potential role of seed priming with ascorbic acid and nicotinamide and their interactions to enhance salt tolerance in broad bean (vicia faba L.). Aust. J. Crop Sci. 7(13):2091-2100.

Barth, C., M. De Tullio, and P. L. Conklin (2006). The role of ascorbic acid in the control of flowering time and the onset of senescence. J. Exp. Bot. 57(8):1657-1665.

Beyer, w.f. and i. Fridovich (1987). Assaying for superoxide dismutase activity: some large consequences of minor changes in condition. Anal. Biochem., 16 (2):559-566.

Bybordi, A.(2012).Effect of ascorbic acid and silicium on photosynthesis, antioxidant enzyme activity, and fatty acid contents in canola exposure to salt stress. J. Integr. Agric. 11, 1610-1620.

Chaves, M. M., J. Flexas, and C. Pinheiro (2009). Photosynthesis under drought and salt stress: regulation mechanisms from whole plant to cell. Ann. Bot. 103(4):551-560.

Chen Z. and D. R. Gallie (2004). The Ascorbic Acid Redox State Controls Guard Cell Signaling and Stomatal Movement. The Plant Cell, Vol. 16, 1143-1162

Devillers, P. (1988). Previsoion du sucre melasse Scurries francases 129: 190-200. In: Cooke, D.A. and R. K. Scott (1993). The sugar beet crop. Chapman and Hall London, pp.262265.

Dickison W.C. (2000) Integrative Plant Anatomy. San Diego: Academic Press.

El-Hariri, D. M., M. S. Sadak and H. M. S. ElBassiouny (2010). Response of flax cultivars to ascorbic acid and $\alpha$-tocopherol under salinity stress condition. Inter. J. of Academic Res. 2(6): 101-109.

Elsayed, A. A. Abdelraouf (2017). Effect of Seed soaking Sugar Beet (Beta vulgaris, L.) Seeds with Gibberellic, Abscisic or Ascorbic Acids on Alleviation of Salinity Stress. Alex. Sci., Exchange J. 38(1): 7481.

Euroconsult (1992). Environmental profile, Fayoum Governorate, Egypt. Al-Shorouk Press, Cairo.

Franks P.J. and G.D. Farquhar (2007). The mechanical diversity of stomata and its significance in gas-exchange control. Plant Physiol 143:78-87.

FWMP. (1999). Fayoum Water Management Project II "Salinisation Monitoring of Lake Qarun Between 1901 and 1998". Technical Report No. 55: 16pp.

Hameed, A., T. Hussain, S. Gulzar, I. Aziz, B. Gul and M.A. Khan (2012).Salt tolerance of a cash crop halophyte Suaeda fruticosa: biochemical responses to salt and exogenous chemical treatments. Acta Physiologiae Plantarum 34:2331 -2340.

Hasanuzzaman, M., M. A. Hossain, J. A. Teixeira da Silva and M. Fujita (2012). "Plant responses and tolerance to abiotic oxidative stress: antioxidant defense is a key factor," in Crop Stress and Its Management: Perspectives and Strategies, V. Bandi, A. K. Shanker, C. Shanker, and M. Mandapaka, Eds., pp. 261316, Springer, Berlin, Germany,.

Jagdish, K. N., A. B. Nishant, K. Deepmala, H. Akhouri and K. Y. Dinesh (2017). Mitigating effect of foliar applied ascorbic acid on morpho-physiological, biochemical changes and yield attributes induced by salt stress in Vigna radiate. Agric. Sci. Digest., 37(2): 112-116.

Le-Docte A. (1927). Commercial determination of sugar beet in the beet roots using Sachs LeDocte process. International Sugar J. 29: 488-492.

Maas, E.V (1986). Salt tolerance of plants. Appl,. Agric. Res. 1(1): 12-26.

Naz, H., N. A. Akram and M. Ashraf (2016). Impact of ascorbic acid on growth and some physiological attributes of cucumber (Cucumis sativus) plants under waterdeficit conditions. Pak. J. Bot., 48(3): 877883.

Panda, S.K. and M.H. Khan (2003). Salt stress influences lipid peroxidation and antioxidants in the leaf of an indica rice (Oryza sativa, L.). Physiol. Mol. Biol. Plants, 9: 273-278.

Raza, S. H., F. Shafiq, M. Chaudhary and I. Khan (2013). Seed invigoration with water, ascorbic and salicylic acid stimulates development and biochemical characters of okra (Ablemoschus esculentus) under normal and saline conditions. Int. J. Agric. Biol. 15, 486-492.

Rhoades, J. and J. Loveday (1990). Salinity in Irrigated Agriculture. In stewart, B.A. and D.R Nielsen (eds.); Irrigation of Agric. Crops. Agron.No. 30, American Soc. pp. 1089-1142.

Ryan, J., S. Garabet, K. Harmsen and A. Rashid (1996). A soil and plant analysis. Manual Adapted for the West Asia and North Africa Region. ICARDA, Aleppo, Syria. $140 \mathrm{pp}$

Sakr, M.T., Z.A. Mohamed, I. A. Marouah and M.T. Zalama (2014). Response of faba bean plants to application of some growth promoters under salinity stress conditions. J. Plant Production, Mansoura Univ., 5 (1): 79-94. 
Samin j., M. Hamayun, S. Wali, A. Bibi, H. Gul and F. Rahim (2016). Foliar application of ascorbic acid mitigates sodium Chloride induced stress in eggplant (solanum melongena 1.). Pak. J. Bot., 48(3): 869-876.

Shaddad, M.A., A.F. Radi, A.M. Abdel-Rahman and M.M. Azooz. (1990). Response of seeds of lupinus termis and Vicia faba to the interactive effect of salinity and ascorbic acid or pyridoxine. Plant \& Soil, 122(2): 177-183.

Shadrin N.V., G.M. EL-Shabrawy, E.V. Anufriieva, M.E. Goher and E. Ragab (2016). 'Long-term changes of physicochemical parameters and benthos in Lake Qarun (Egypt): Can we make a correct forecast of ecosystem future, Knowl. Manag. Aquat. Ecosyst. 417, 18:1-11.

Shao, H. B., L. Y.Chu, Z. H. Lu, and C. M. Kang (2008). Primary antioxidant free radical scavenging and redox signaling pathways in higher plant cells. Int. J. Biol. Sci. 4(1): 814.

Smirnoff, N. (1996). The function and metabolism of ascorbic acid in plants. Ann. Bot., 78: 661-669.

Snedecor G.W. and Cochran W.G. (1980). Statistical Methods. 7 ed., Iowa State Univ. Press, Ames, Iowa, USA, pp 255-269.

Wettstein, D. (1957). Chlorophyll, Letal under submikro svopische formmech, sallplastiden- Exptl Cell Ser., 12: 427-433.

Yin H., L. Xu and N. A. Porter (2011). "Free radical lipid peroxidation: Mechanisms and analysis," Chem. Rev., 111 (10): pp. 59445972.

Zhang, Y. (2013). Biological role of ascorbate in plants (Chapter 2). Springer Briefs in Plant Science. 


\title{
تأثير طرق إضافة وتركيزات لحمض الأسكوربيك على بنجر السكر تحت ظروف الاجهاد الملحى

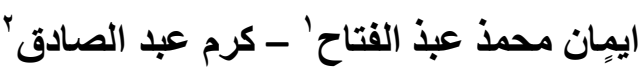

\author{
ا قسم بحوث الفسيولوجي والكيمياء بمعهز بحوث الححاصيل السكرية- مركز البحوث الزراعية \\ r قسم بحوث المعاملات الزراعية بمعهد بحوث المحاصيل السكرية- مركز البحوث الزراعية
}

الاجهاد الملحى هو احد عوامل الإجهاد البيئى التي تؤثر على نمو النبات ويقلل من إنتاجيتها. تعتبر مضادات الأكسدة واحدة من الأساليب والاستراتيجيات المتبعة لتخفيف الآثار الضارة لإجهاد الملوحة على النباتات و لتقليل تأثير الإجهاد

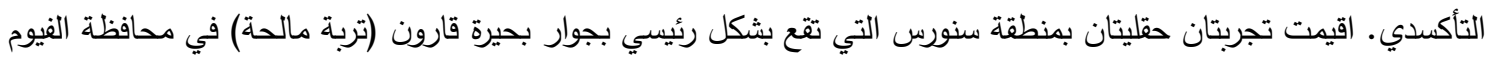

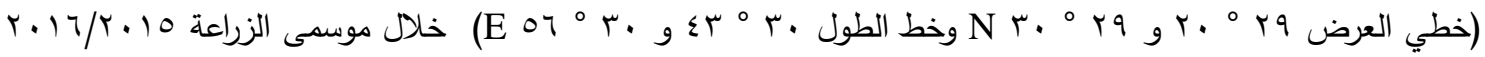

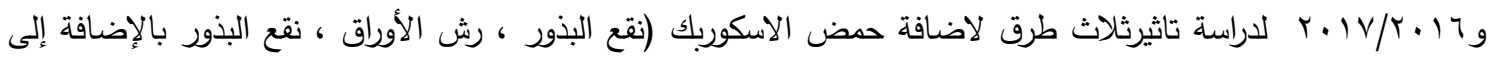

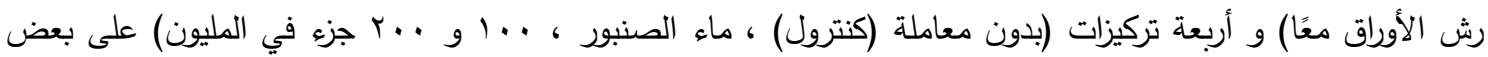
الخصائص الكيميائية الحيوية والفسيولوجية ونثاط بعض إنزيمات مضادات الأكسدة وكذلك على بعض صفات النهو وحاصل وجودة بنجر السكر المنزرع تحت ظروف الاجهاد الملحى. تم استخدام تصميم الثرائح المتعامدة في ثلاث مكررات ،.

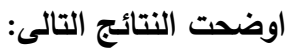

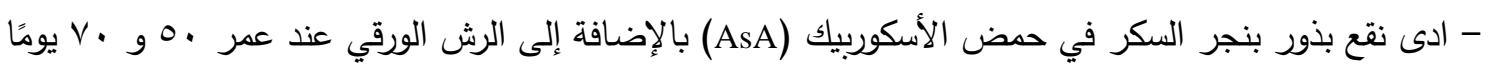

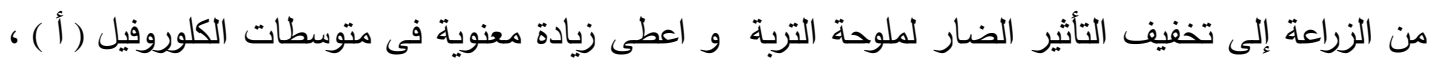
(ب) والكاروتينيدات و دليل مساحة الاوراق و زيادة معنوية في فعالية مضادات الأكسدة الإنزيمية السوبرأوكسيد دسميوتيز (SOD) و الكاتاليز (CAT) و مكونات المحصول والنسب المئوية للسكروز ٪ و وانخفاض الشوئب في

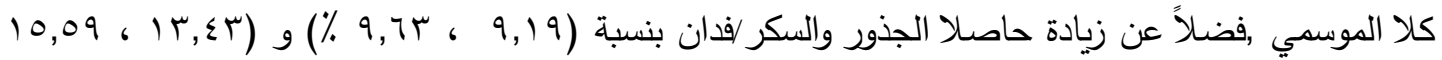
\% ) مقارنة بمعاملتى نقع البذور أو الرش الورقى في الموسم الأول.نفس الاتجاة كان فى الموسم الثاني. - دلت النتائج على ان تطبيق . . ج جزء في المليون من حمض الأسكوربيك كان أكثر فاعلية وزاد حاصل الجذور و حاصل السكر والنسب المئوية للسكروز وانخفاض الشوائب مقارنة بالكنترول فى كلا الموسمين. - تم تسجيل أعلى مساحة و أقل كثافة للثغور و نسبة الثغور المغلقة للأسطح العلوية والسفلية لأوراق بنجر السكر من خلال نقع البذور مع الرش الورقي بحمض الاسكوربك بتركيز .. جزء في في المليون. - تحقق اعلي حاصل جذور وحاصل سكر عند نقع البذور مع الرش الورقي لحمض الاسكوربك بتركيز . .. جزئ

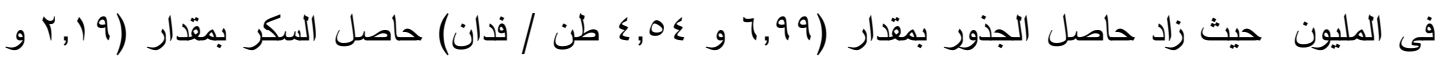

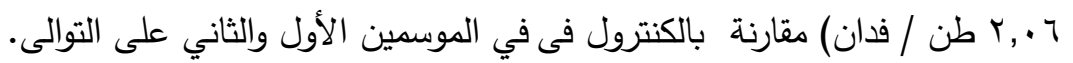

يتضح من هذا البحث انه يمكن التغلب على الآثار الضارة للإجهاد الناشئ عن ملوحة التربة على صفات النمو

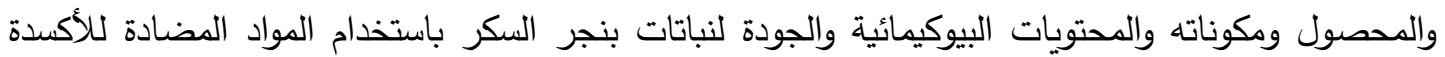

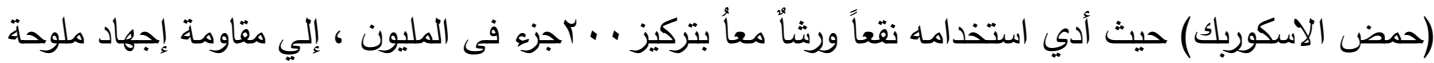

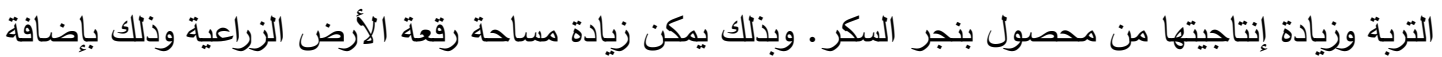

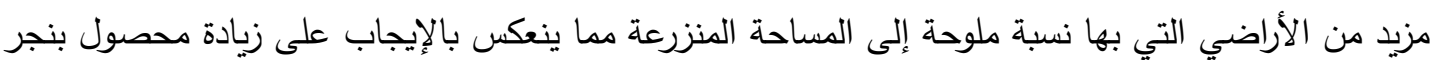

